\title{
The mediating effect of auditor dysfunctional behavior on Machiavellian character and time budget pressure of audit quality
}

\author{
Intan Kalvika Sari Putu ${ }^{a^{*}}$, Ni Ketut Rasmini ${ }^{a}$, I Ketut Budiartha ${ }^{a}$ and A.A Gde Putu Widanaputra ${ }^{a}$
}

${ }^{a}$ Faculty of Economics and Business, Udayana University, Bali, Indonesia

\begin{tabular}{l}
\hline C H R O N I C L E \\
\hline Article history: \\
Received May 152020 \\
Received in revised format May \\
162020 \\
Accepted July 62020 \\
Available online \\
July 122020 \\
\hline Keywords: \\
Machiavellian characteristic \\
Time budget pressure \\
Auditor dysfunctional behavior \\
Audit quality
\end{tabular}

Article history:

Received May 152020

Received in revised format May

Accepted July 62020

Available online

Keywords:

Machiavellian characteristic

Auditor dysfunctional behavio

\begin{abstract}
A B S T R A C T
The purpose of this study is to examine the auditor's dysfunctional behavior mediating the influence of Machiavellian characteristic and time budget pressure on audit behavior. This study took a sample of all auditors at the Public Accountant Office (KAP) of the Province of Bali. Determination of the sample was accomplished based on the nonprobability sampling method with saturated sample technique. The research sample was 94 auditors and questionnaires were distributed among them and managed to collect 65 questionnaires. Data analysis was performed using the path analysis model. The results show the auditor's dysfunctional behavior fully mediated the influence of Machiavellian traits on audit quality, while the auditor's dysfunctional behavior mediated the partial effect of time budget pressure on audit quality. The results of this study can be considered for auditors and input for IAPI in improving audit quality by suppressing and avoiding the auditor's dysfunctional behavior due to the influence of Machiavellian characteristic and time budget pressure.
\end{abstract}

\section{Introduction}

The public accountant profession is a profession of public trust, where the public expects a free and impartial assessment of the information presented by company management in financial statements (Mulyadi, 2014; Rastina et al., 2018). In the audit standard, an auditor is required to have sufficient ability, expertise and technical training in conducting an audit and to have a professional code of ethics in carrying out his duties as an auditor. An auditor has the duty to conduct an audit with the aim of seeking information about what is carried out in an entity being examined, comparing results with established criteria, as well as approving or rejecting results by providing recommendations on corrective actions (Marbun, 2015; Khudhair et al., 2019).

In order to obtain competent and sufficient audit evidence, before conducting the audit, the public accounting firm (KAP) first prepares the audit program and audit time budget. The audit program is a collection of audit procedures that must be carried out during the audit process, while the audit time budget is an estimate or estimated time allocated for carrying out each audit procedure (Hastuti, 2013; Arens et al., 2015; Sihombing, 2019). Audit procedures that have been well designed and implemented will give good results, thereby increasing user confidence. The trust of users of audited financial statements in the public accounting profession is very dependent on the quality of audits produced by KAP (Nugraha, 2016).

Audit quality is said as a condition where an auditor will find and report a non-compliance with the principles that occur in the client's accounting report (De Angelo, 1981). Audit procedures that are carried out carefully and thoroughly will help KAP in

* Corresponding author.

E-mail address: putuintan.kalvika96@gmail.com (I. K. S. Putu)

(C) 2020 by the authors; licensee Growing Science, Canada doi: $10.5267 /$ j.ac.2020.7.009 
producing quality audit services. Audit quality degradation will occur if an auditor takes dysfunctional actions in carrying out audit procedures.

The auditor's dysfunctional behavior is any action taken by the auditor in the implementation of the audit program that can reduce audit quality directly or indirectly. Actions that can reduce audit quality directly in the audit program are called audit quality reduction behaviors, while those that can reduce audit quality indirectly are called underreporting of time behavior (Anita et al., 2018).

Audit quality reduction behavior is the auditor's actions taken during the implementation of audit procedures that reduce the effectiveness of audit evidence collected. Audit quality reduction behavior can be done with various actions for example; premature termination of audit procedures, shallow review of client documents, does not investigate the appropriateness of the accounting treatment applied by the client, acceptance of inadequate client explanations, reduces audit work than it should do, and does not expand the scope of auditing when a questionable transaction or post is detected (Kelley \& Margheim, 1990).

A serious threat to audit quality occurs since audit evidence collected during the implementation of audit procedures is incompetent and sufficient as an adequate basis for the auditor to express an opinion on the fairness of the audited financial statements (Sudirjo, 2018). Unethical behavior by individuals in organizations can be caused by personal characteristics, situational and interactions between these factors. Dysfunctional audit behavior can be categorized as unethical behavior, so the tendency of the auditor to perform such actions can be influenced by the characteristics or personality of the individual auditor (Silaban, 2011; Kristianti, 2017; Aisyah \& Sukirman., 2015; Alfitman, 2017; Alkali et al., 2018).

Machiavellianism was taught by a political philosopher named Niccolo Machaivelli in 1469-1527. This understanding explains an antisocial personality that does not pay attention to conventional morality and has a low ideological commitment. Here, a Machiavellian has a tendency to be selfish, manipulative and aggressive. In terms of business this type can be accepted but different from the accounting profession, especially auditors. Auditors are required to have ethical responsibilities that are even more than the responsibilities of other professions. Auditors who have this trait will tend to cause poor audit quality, this is because an auditor will act selfish, manipulative.

Situational factors in this study are budget constraints on audit time. Time budget constraint is a condition where the auditor faces time limitations in the implementation of the audit program. These time limitations arise from the time limit set by the KAP in completing an audit procedure. Time limitation becomes its own obstacle in competing with one another. Intensive competition in the audit market requires KAP to make efficiency through controlling audit costs. To improve efficiency one of the ways that KAP is often adopted is to set a strict audit time budget (McNair-Conolly, 1991) in (Kristanti et al., 2017). Devi and Ramantha's research (2017) found that time budget pressure is the biggest cause of declining audit quality. A tight audit time budget can cause the auditor to feel pressure in carrying out audit procedures due to an imbalance between the time available and the time needed to complete the audit task, and subsequently these conditions can encourage the auditor to take dysfunctional audit actions.

The research of Saryati and Raden (2016) found that Machiavellian characteristic directly had a negative and not significant effect on audit quality. However, these results are different from the research conducted by Srini (2015), Yulianti (2016) found that Machiavellian characteristic has a positive and not significant effect on audit quality. Research by Ningsih and Yaniartha S (2013) found the results that time budget pressure had a negative effect on audit quality. Kurnia et al. (2014) found the results that time budget pressure had a significant effect on audit quality. In line with research by Ratha and Ramantha (2015), Ariningsih and Mertha (2017), Widiani, Sulindawati, and Herawati (2017) found that time budget pressure had a negative effect on audit quality. However, there are differences in results made by Gundry and Liyanarachchi (2007), Zam and Rahayu (2018), and Utami and Sirajuddin (2016) showing the results that time budget pressure does not significantly influence audit quality. Researchers Devi and Ramantha (2017) found that partially Machiavellian characteristichad a significant positive effect on auditor's dysfunctional behavior. Limanto and Sukartha (2019) found the result that Machiavellian characteristic had a positive effect on auditor's dysfunctional behavior. Research by Suprianto (2009), Sari et al., (2016) found that time budget pressure had a significant positive effect on auditor's dysfunctional behavior. However, in contrast to the results of the study Srini (2015) found that Machiavellian trait influences but is not significant on auditor's dysfunctional behavior. Research conducted by Devi and Ramantha (2017) found the results that time budget pressure partially had a significant positive effect on auditor's dysfunctional behavior.

Previous research emphasizes more on the influence of time budget pressure on audit quality and there is still little research that discusses the Machiavellian characteristic of audit quality. In this study trying to develop previous research by adding the auditor's dysfunctional behavior variable as a mediating variable. This is considered necessary because there are still public accountants involved in cases that violate the code of ethics of the public accounting profession. The auditor's dysfunctional behavior can affect the quality of the audit produced, which means that the auditor's dysfunctional behavior has a direct and indirect effect on audit quality (Setiawaty, 2013; Rohman, 2018). Kelley and Margheim's (1990) research on the impact of time 
budget pressure, personal characteristics and leadership style on auditor's dysfunctional behavior shows that there are several behaviors that can directly reduce audit quality, including: too early to complete audit steps, failing to understand principles accounting, reviewing client documents in depth and accepting weak explanations from clients. Whereas behavior that has no direct effect in reducing audit quality is to report audit time with a total time that is shorter than the actual time or reporting audit time that is less.

\section{Literature Review and Hypotheses Development}

Machiavellian characteristic is a negative trait and has a negative impact on a profession, especially for auditors because it ignores the importance of integrity and honesty in achieving goals. Individuals who have high Machiavellian characteristic try to take advantage of the situation for personal gain and tend not to comply with regulations (Ghosh \& Crain, 1996) in (Prawitasaria et al., 2018). In accordance with the dispositional attributions in attribution theory, Machiavellian characteristic is an internal cause that refers to aspects of individual behavior contained in a person. An auditor who has this trait tends to take action to have a manipulative attitude in his life, this means an auditor will perform a dysfunctional behavior in doing his work. Machiavellian characteristic is consistently related to dysfunctional behavior, which is a direct and serious threat to audit quality because Machiavellian characteristic is a condition where the auditor feels his personal interests are more than anything.

The results of Chrismastuti and Purnamasari's (2013), Nurfadilah and Junaid (2019) studies show that the higher a person's tendency to take unethical actions if the Machiavellian characteristic they have is higher. An auditor who has a tendency to be Machiavellian is likely to take actions that violate the rules of professional ethics so as to cause dysfunctional behavior. Saputri and Wirama's research (2015) which states that auditors are increasingly vulnerable to dysfunctional behavior if the auditor's Machiavellian characteristic is high. Devi's research (2016) states that the influence of Machiavellian characteristic has an influence simultaneously and affects the auditor's dysfunctional behavior. Martini's research (2019) supports previous research which states that Machiavellian characteristic will improve auditor's dysfunctional behavior. Research Pradnyanita and Sujana (2019) get empirical evidence that the characteristic of Machiavellian has a positive and significant effect on the auditor's dysfunctional behavior, which means that the Machiavellian characteristic has a negative influence on a quality of organizational performance. It can also be said that the lower the Machiavellian characteristic of the auditor, the better the audit quality will be.

$\mathrm{H}_{1}$ : Auditor's dysfunctional behavior mediates the influence of Machiavellian traits on audit quality.

A tight time budget prevents the auditor from completing all the audit procedures that are supposed to be carried out because the pressure exerted by the supervisor is considered impossible to fulfill by the auditor. This will indicate the auditor's dysfunctional behavior to meet the given time budget (DeZoort \& Lord, 1997). When time budget pressure increases, the auditor's dysfunctional behavior will also increase. In addition, risk assessment and sample size are reduced when the auditor is under time pressure (Svanberg \& Öhman, 2013).

Attitude change theory and work stress theory that explains how the relationship of nonconformity will motivate someone to eliminate the discrepancy, when someone is under pressure there is a possibility of response from the auditor to behave higher deviations. Time budget pressure is consistently related to dysfunctional behavior, which is a direct and serious threat to audit quality because time budget pressure is a condition where the auditor is required to make efficiency over the time budget that has been prepared or there are time constraints in a very tight and rigid budget. Research by Yuen et al. (2013); Svanström (2016); and Umar et al. (2017) prove that there is a positive influence of time budget pressure on the auditor's dysfunctional behavior. Research by Ningsih and Yaniartha S (2013) shows that time budget pressure has a negative effect on audit quality. Research by Utami and Sirajuddin (2016), Kurniawan et al (2019) shows that time budget pressure does not have a significant effect on audit quality.

$\mathrm{H}_{2}$ : The auditor's dysfunctional behavior mediates the effect of time budget pressure on audit quality.

\section{Methods}

This research was conducted at a Registered Public Accountant Office in Bali based on the Public Accountant Firm Directory and Public Accountant published by the Indonesian Public Accountants Association (IAPI) in 2020. The time of the study was 2020. The population in this study was KAP auditors in Bali, amounting to 94 person. Sampling in this study using Saturated Samples. Saturated sample which means the entire sample will be selected so that it can reflect the characteristic of the population.

The research hypothesis testing was carried out using the path analysis model and data processing using the SPSS 23 program. The path analysis model was used to analyze patterns of relationships between variables in order to determine the direct or indirect influence of a set of independent variables on the dependent variable. 


\section{Results and Discussion}

\subsection{Description of Research Variables}

The results of descriptive statistics of variables can be seen in Table 1 .

Table 1

Variable Descriptive Statistics Results

\begin{tabular}{|c|c|c|c|c|c|}
\hline Variable & $\mathrm{N}$ & Min & Max & Mean & $\begin{array}{c}\text { Std. } \\
\text { Deviation }\end{array}$ \\
\hline Machiavellian Characteristic (X1) & 65 & 55 & 90 & 72,66 & 9,322 \\
\hline Time Budget Pressure (X2) & 65 & 17 & 28 & 22,58 & 2,75 \\
\hline Auditor Dysfunctional Behavior (X3) & 65 & 15 & 60 & 37,11 & 10,23 \\
\hline Audit Quality (Y) & 65 & 18 & 44 & 32,22 & 7,63 \\
\hline
\end{tabular}

Primary Data, 2020

Machiavellian characteristic has the lowest value of 55, the highest value of 90, an average value of 72.66 and a standard deviation of 9.32. The average value of 72.66 indicates the average response of respondents is at a moderate level that is in the range $>69-76$. This means that respondents or auditors is Machiavellian at a moderate level.

The time budget pressure has the lowest value of 17 , the highest value of 28 , an average value of 22.58 and a standard deviation of 2.75. The average value of 22.58 indicates that the average respondent's answer is at a moderate level in the range $>21.4-23.6$ (appendix 3). This means that respondents or auditors have time budget pressure at a moderate level.

The auditor's dysfunctional behavior has the lowest value of 15, the highest value of 60, an average value of 37.11 and a standard deviation of 10.23. The average value of 37.11 indicates the average response of respondents is at a moderate level that is in the range $>33-42$. This means that respondents or auditors have auditor dysfunctional behavior at a moderate level.

Audit quality has the lowest value of 18, the highest value of 44, an average value of 32.22 and a standard deviation of 7.63 . The average value of 32.22 indicates the average response of respondents is a moderate level that is in the range $>28.4-33.6$. This means that the respondent or auditor has a fairly good audit quality.

\subsection{Evaluation of Fulfillment of Assumption Path Analysis}

In the path analysis model, the relationship between variables is linear and additive. Linearity test uses curve fit and applies the parsimony principle, which is when all models are linear. Based on the processed data as shown in Table 5.10 it can be seen that all the relationships between studies show a linear relationship. Therefore, the analysis model created is feasible to be applied.

\section{Table 2}

Summary of Linear Models

\begin{tabular}{|c|c|c|c|c|c|c|}
\hline Relationship & $\mathrm{R}^{2}$ & $\mathrm{~F}$ & df1 & $\mathrm{df} 2$ & P Value & Description \\
\hline $\mathrm{X}_{1} \rightarrow \mathrm{X}_{3}\left(\mathrm{~b}_{1}\right)$ & 0,414 & 44,519 & 1 & 63 & 0,000 & Significant \\
\hline $\mathrm{X}_{2} \rightarrow \mathrm{X}_{3}\left(\mathrm{~b}_{2}\right)$ & 0,366 & 36,443 & 1 & 63 & 0,000 & Significant \\
\hline $\mathrm{X}_{1} \rightarrow \mathrm{Y}\left(\mathrm{b}_{3}\right)$ & 0,342 & 32,705 & 1 & 63 & 0,000 & Significant \\
\hline $\mathrm{X}_{2} \rightarrow \mathrm{Y}\left(\mathrm{b}_{4}\right)$ & 0,390 & 40,290 & 1 & 63 & 0,000 & Significant \\
\hline $\mathrm{X}_{3} \rightarrow \mathrm{Y}\left(\mathrm{b}_{5}\right)$ & 0,505 & 64,145 & 1 & 63 & 0,000 & Significant \\
\hline
\end{tabular}

Information:

$\mathrm{X} 1 \rightarrow \mathrm{X} 3=$ Effect of Machiavellian characteristic on auditor's dysfunctional behavior

$\mathrm{X} 2 \rightarrow \mathrm{X} 3=$ Effect of time budget pressure on auditor's dysfunctional behavior

$\mathrm{X} 1 \rightarrow \mathrm{Y}=$ Effect of Machiavellian characteristic on audit quality

$\mathrm{X} 2 \rightarrow \mathrm{Y}=$ Effect of time budget pressure on audit quality

$\mathrm{X} 3 \mathrm{Y}=$ Effect of auditor's dysfunctional behavior on audit quality

\subsection{Evaluation of Model Validity}

Test the validity of the model in path analysis, using formula number 3 which checks the validity of a model error. the calculation results can be seen as follows. 


$$
\begin{aligned}
P_{e 1} & =\sqrt{1-R^{2}} \\
P_{e 1} & =\sqrt{1-0,526} \\
& =0,688 \\
P_{e 2} & =\sqrt{1-R^{2}} \\
P_{e 2} & =\sqrt{1-0,581} \\
& =0,647
\end{aligned}
$$

Calculation of the Total Determination Coefficient

$$
\begin{aligned}
& R_{m}^{2}=1-P_{e 1}^{2} P_{e 2}^{2} \\
& R_{m}^{2}=1-(0,688)^{2}(0,647)^{2} \\
& R_{m}^{2}=0,785
\end{aligned}
$$

$P_{e i}$ is the standard error of estimate from the regression model. $P_{e 1}$ is 0.688 and $P_{e 2}$ is 0.647 . The coefficient of determination of the total structural equation of the research model in accordance with the calculations obtained the value of $R_{m}^{2}=0.785$. The coefficient of total determination of 0.785 means that 78.5 percent of the information contained can be explained by the model formed, while the remaining 21.5 percent is explained by other variables outside the model formed.

\section{Regression Analysis Results}

Based on the results of processed regression data, the path coefficient can be summarized as shown in Table 3 .

Table 3

Path Analysis

\begin{tabular}{lllllll}
\hline \multicolumn{1}{c}{ Regresion } & \multicolumn{1}{c}{$\begin{array}{c}\text { Coefficient } \\
\text { Error }\end{array}$} & $\begin{array}{c}\text { Coefficient } \\
\text { Standard }\end{array}$ & Standard Error & $\mathrm{t}_{\text {value }}$ & $P$ Value & Description \\
\hline $\mathrm{X}_{1} \rightarrow \mathrm{X}_{3}\left(\mathrm{~b}_{1}\right)$ & 0,502 & 0,457 & 0,110 & 4,565 & 0,000 & Significant \\
$\mathrm{X}_{2} \rightarrow \mathrm{X}_{3}\left(\mathrm{~b}_{2}\right)$ & 1,425 & 0,383 & 0,373 & 3,823 & 0,000 & Significant \\
$\mathrm{X}_{1} \rightarrow \mathrm{Y}\left(\mathrm{b}_{3}\right)$ & $-0,140 \mathrm{a}_{1}$ & $-0,171$ & $0,090 \mathrm{sa}_{1}$ & $-1,558$ & 0,124 & Not. Sig \\
$\mathrm{X}_{2} \rightarrow \mathrm{Y}\left(\mathrm{b}_{4}\right)$ & $-0,779 \mathrm{a}_{2}$ & $-0,281$ & $0,293 \mathrm{sa}_{2}$ & $-2,662$ & 0,010 & Significant \\
$\mathrm{X}_{3} \rightarrow \mathrm{Y}\left(\mathrm{b}_{5}\right)$ & $-0,321 \mathrm{~b}$ & $-0,430$ & $0,090 \mathrm{sb}$ & $-3,575$ & 0,001 & Significant \\
\hline
\end{tabular}

Primary Data, 2020

Based on Table 3 it can be explained that the Machiavellian characteristic and time budget pressure have a positive and

\begin{tabular}{|c|c|c|c|c|c|c|c|c|c|}
\hline \multirow[t]{2}{*}{ Variable } & \multicolumn{3}{|c|}{ X1 } & \multicolumn{3}{|c|}{$\mathrm{X} 2$} & \multicolumn{3}{|c|}{$\mathrm{X} 3$} \\
\hline & Direct & Indirect & Total & Direct & Indirect & Total & Direct & Indirect & Total \\
\hline $\mathrm{X} 3$ & 0,457 & . & 0,457 & 0,383 & & 0,383 & . & . & \\
\hline Y & $-0,171$ & $-0,368$ & $-0,539$ & $-0,281$ & $-0,446$ & $-0,727$ & $-0,430$ & & $-0,430$ \\
\hline
\end{tabular}
significant effect on the auditor's dysfunctional behavior. In other equations, Machiavellian characteristic does not affect audit quality. While the time budget pressure and auditor's dysfunctional behavior have a negative and significant effect on audit quality.

The structural equation for the model is:

Model 1: $\mathrm{X}_{3}=0,457 \mathrm{X}_{1}+0,383 \mathrm{X}_{2}+\mathrm{e}_{1}$

Model 2: $\mathrm{Y}=-0,171 \mathrm{X}_{1}-0,281 \mathrm{X}_{2}-0,430 \mathrm{X}_{3}+\mathrm{e}_{2}$

\section{Table 4}

Coefficients of Direct, Indirect, and Total Variables

Primary Data, 2020

Based on Table 4 it can be explained that the direct influence of the variable Machiavellian characteristic on the auditor's dysfunctional behavior is 0.457 . There is no indirect effect between these variables so that the total effect remains at 0.457 . While the direct influence of time budget pressure on the auditor's dysfunctional behavior is 0.383 . There is no indirect effect of these variables, so the total effect remains at 0.383 .

The direct effect of Machiavellian characteristic on audit quality is $-0,171$. The indirect effect of Machiavellian characteristic on audit quality through the auditor's dysfunctional behavior was obtained from (b1 x b5) namely $(0.457 \mathrm{x}-0.430)=-0.197$. So that the total influence of the quality of audit quality Machiavellian $(-0,171+(-0,197))=-0,368$. 
The direct effect of time budget pressure on audit quality is -0.281 . The indirect effect of time budget pressure on audit quality through the auditor's dysfunctional behavior is obtained from (b2 x b5) namely $(0.383 \times-0.430)=-0.165$. So that the total influence of budget pressure on audit quality time $(-0,281+(-0,165))=-0,446$.

The direct effect of the auditor's dysfunctional behavior on audit quality is -0.430 . There is no indirect effect of these variables, so the total effect remains at -0.430 .

Table 5

Summary of Indirect Effects

\begin{tabular}{cccccccc}
\hline Relationship & Mediate & Coefficient & Std. Error & t statistic & $\rho$ value & Description \\
\hline $\mathrm{X}_{1} \rightarrow \mathrm{Y}$ & $\mathrm{X}_{3}$ & $-0,368$ & 0,057 & 2,810 & 0,0049 & Significant \\
$\mathrm{X}_{2} \rightarrow \mathrm{Y}$ & $\mathrm{X}_{3}$ & $-0,446$ & 0,175 & 2,607 & 0,0091 & Significant \\
\hline
\end{tabular}

Primary Data, 2020

Based on Table 5 it can be explained that the Machiavellian Characteristic and time budget pressure on audit quality through the auditor's dysfunctional behavior has a negative and significant effect.

\section{Hypothesis Testing 1}

The auditor's dysfunctional behavior mediates the influence of Machiavellian traits on audit quality. Based on the results of mediation testing in Appendix 11, it shows that the z-count of 2.81 is greater than 1.96 or the p-value of 0.0049 is smaller than 0.05. Hypothesis one is accepted, which means the auditor's dysfunctional behavior mediates the influence of Machiavellian Characteristicon audit quality. Therefore, Machiavellian Characteristic (X1) does not directly have a significant effect on audit quality (Y), while indirectly there is an influence of Machiavellian Characteristic(X1) on audit quality (Y) through the auditor's dysfunctional behavior variable (X3). Then the auditor's dysfunctional behavior variable is classified as "full mediation" which means that the Machiavellian Characteristicis not able to significantly influence audit quality without going through the auditor's dysfunctional behavior.

\section{Hypothesis Testing 2}

The auditor's dysfunctional behavior mediates the effect of time budget pressure on audit quality. Based on the results of mediation testing in Appendix 11, it shows that the z-count of 2.60 is greater than 1.96 or a p-value of 0.0091 is smaller than 0.05. This second hypothesis is accepted, which means that dysfunctional behavior mediates the effect of time budget pressure on audit quality. Because time budget pressure (X2) directly has a significant effect on audit quality (Y), while indirectly there is an influence of time budget pressure (X2) on audit quality (Y) through the auditor's dysfunctional behavior variable (X3). Then the auditor's dysfunctional behavior is classified as "partial mediation" which means that time budget pressure is able to directly influence audit quality without going through the auditor's dysfunctional behavior.

\section{Effect of Machiavellian Characteristic on Audit Quality through Auditor's Dysfunctional Behavior}

Machiavellian Characteristic is an individual personality that justifies any means in achieving something he wants. An auditor who has this nature or the presence of Machiavellian Characteristic in the auditor makes the auditor more susceptible to dysfunctional behavior or taking unethical actions in which an auditor will try to exploit the situation for personal gain or achieve the desired targets and tend to not comply with the rules.

This research supports attribution theory that explains how individuals behave when they are caused by dispositional or internal factors. Dispositional or internal factors, namely the behavior of a person in research is an auditor who comes from the person concerned caused by psychological factors that precede his behavior (Turangan, 2016; Palulu et al., 2018). In this case the Machiavellian Characteristic is a dispositional factor that influences a person's behavior in acting. The results of this study stated that if the auditor has a high Machiavellian Characteristic will indicate an increase in auditor dysfunctional behavior. Conversely, if the level of Machiavellian Characteristic of an auditor is low, the auditor's dysfunctional behavior will also decrease. The cluster of Machiavellian Characteristic in this study is at a sufficient level with a range of values $>69-76$. Seeing this, it means that an auditor has enough Machiavellian Characteristic in him that will trigger dysfunctional behavior. Machiavellian Characteristic is consistently related to dysfunctional behavior, which is a direct and serious threat to audit quality. Auditors who have high Machiavellian Characteristic then low ethical behavior that causes the auditor to conduct audit dysfunctional behavior which in turn will reduce the quality of audit results or the resulting audit results are low. Conversely, if the Machiavellian Characteristic is low then high ethical behavior, low dysfunctional audit behavior and high audit quality.

The results of this study are in line with research by Purnamasari (2006), Saputri and Wirama (2015), Winanda (2017), and Pranyanita and Sujana (2019) which state that Machiavellian traits have a positive effect on dysfunctional audit behavior. In the research of Bulutoding and Paramitasari (2017) found that individuals with high Machiavellian traits tended to be more lying, 
less moral, and more manipulative. In this study the dysfunctional behavior variable is able to mediate fully in audit quality, this is because auditors who have Machiavellian Characteristic will behave dysfunctional in carrying out their work or duties so as to affect the quality of the resulting audit which means a decline in audit quality.

\section{Effects of Time Budget Pressure on Audit Quality through the Auditor's Dysfunctional Behavior}

In conducting an audit program, time budget pressure is a condition felt by the auditor when the auditor is under pressure to be able to complete the audit assignment with an agreed time budget that affects the auditor's behavior (Said and Munandar, 2018). Research conducted by Silaban (2011) says that if the auditor feels there is time budget pressure in the audit program, then the auditor may act as if he did not conduct the audit procedures as they should, but the auditor claims that they have performed the audit procedures properly so that the auditor's dysfunctional behavior occurs. Based on previous studies such as those conducted by Otley \& Pierce (1996), Pierce \& Sweeney (2004), Silaban (2011), and Yuen et al. (2013), Lendi and Sopian (2017) which prove that auditors respond to time budget constraints by taking dysfunctional actions in audits.

Auditors who experience time budget pressure with high intensity will increase the auditor's dysfunctional behavior, conversely if the level of time budget pressure experienced by the auditor is low, the auditor's dysfunctional behavior will decrease. The time budget pressure cluster in this study is at a sufficient level with a range of values $>21.4-23.6$. Seeing this, it means that an auditor feels enough time budget pressure in carrying out audit tasks. This will certainly lead to dysfunctional behavior in conducting audits. The results of research by Broberg et al., (2016), Nor et al., (2017) found that audit time budget pressure negatively affects audit quality. Svanström (2016), Lendi and Sopian (2017), Devi and Ramantha (2017); Mangiwa et al., (2017); Siregar (2018) which proves that there is a positive influence of time budget pressure on the auditor's dysfunctional behavior. High time budget pressure will make the auditor depressed and the auditor tends to do anything without exception doing deviant behavior to achieve his goals. This research supports the attribution theory which is shown by the higher time budget pressure, the higher the auditor's opportunity to perform dysfunctional audit behavior and supports work stress theory and attitude change theory in which time budget pressure causes individual stress arising from unbalanced tasks and tight time available and influence professional ethics through the attitudes, values, attention, and behavior of auditors.

Research by Fatimah (2012), Setiawaty (2013), and Kustinah (2013), Trishapsari and Anisykurlillah (2016), Ida Perwati and Sutapa (2016), Purwaningsih and Suputra (2018) which prove that auditor dysfunctional behavior negatively affects audit quality. Fatimah (2012) states that the auditor's dysfunctional behavior will provide a direct threat to the reliability of an audit process and will have an adverse impact in the future, such as audit reduction behavior in future audits so that increasing dysfunctional behavior will reduce the quality of results an audit. Time budget pressure is a potential cause of the decline in audit quality behavior, which means that with a high time budget pressure can cause a decrease in the level of audit quality, because with a limited time budget causes the auditor to tighten the programs implemented to be able to adjust to the limited time, so that the audit cannot be done more thoroughly and carefully because of the budgeted time limits (Primastuti \& Suryandari, 2014).

Dysfunctional auditors mediate time budget pressure on audit quality, because time budget pressure is consistently related to dysfunctional behavior, which is a direct and serious threat to audit quality because time budget pressure is a condition where the auditor is required to make efficiency over the time budget that has been prepared or there are time restrictions in a very tight and rigid budget. This study shows that the higher the time budget pressure, the auditor tends to behave dysfunctional so that the lower the audit quality. Conversely, if the time budget pressure is low, the auditor tends not to behave dysfunctional so that it will increase or improve audit quality.

\section{Conclusion}

Based on the results of the analysis and discussion of the results of this study conclusions can be drawn as follows:

1) The auditor's dysfunctional behavior mediates the effect of Machiavellian traits on audit quality. If an auditor has a high Machiavellian nature, the auditor will behave dysfunctional in conducting his audit thereby reducing audit quality.

2) The auditor's dysfunctional behavior mediates the effect of time budget pressure on audit quality. If the auditor in carrying out his duties feels the pressure of the time budget, the auditor will perform dysfunctional behavior in conducting the audit which results in a decrease in audit quality.

\section{References}

AAA Financial Accounting Standard Committee (2000). Commentary: SEC Auditor Independence Requirements. Accounting Horizons, 15(4), December 2001, 373-386.

Aisyah, E. A., \& Sukirman. (2015). Hubungan Pengalaman, Time Budget Pressure, Kompensasi terhadap Kualitas Audit pada Kantor Akuntan Publik (KAP) di Kota Semarang. Accounting Analysis Journal, 3(4), 457-465.

Alfitman. (2017). Konstruk Disonansi Kognitif Dalam Penelitian Perilaku Konsumen: Apakah Popularitasnya Memang Sudah Meredup? EKOBIS-Ekonomi Bisnis, 22(1), 44-57. 
Alkali, M., Zuru, N., \& Kegudu, D. (2018). Book value, earnings, dividends, and audit quality on the value relevance of accounting information among Nigerian listed firms. Accounting, 4(2), 73-82.

Anita, R., Nanda, S. T., Zenita, R., \& Abdillah, M. R. (2018). Locus of control, penerimaana auditor atas dysfunctional audit behavior and intention to quit. Jurnal Dinamika Akuntansi Dan Bisnis, 5(1), 43-54.

Ariningsih, P. S., \& Mertha, I. M. (2017). Pengaruh Independensi, Tekanan Anggaran Waktu, Risiko Audit, Dan Gender Pada Kualitas Audit. E-Jurnal Akuntansi, 18, 1545-1574.

Broberg, P., Tagesson, T., Argento, D., Gyllengahm, N., \& Mårtensson, O. (2016). Explaining the influence of time budget pressure on audit quality in Sweden. Journal of Management and Governance. https://doi.org/10.1007/s10997-016-9346-4

Bulutoding, L., \& Paramitasari, R. D. A. (2017). Pengaruh Sifat Machiavellian dan Love of Money Terhadap Perilaku Etis Atditor. Jurnal Ilmiah Akuntansi Peradaban, 114-131.

Chrismastuti, A. A., \& Purnamasari, V. (2013). Hubungan Sifat Machiavelian, Pembelajaran Etika Dalam Mata Kuliah Etika, dan Sikap Etis Akuntan: Suatu Analisis Perilaku Etis Akuntan dan Mahasiswa Akuntansi di Semarang. SNA VII DenpasarBali, 2-3 Desember 2004, 53(9), 1689-1699. https://doi.org/10.1017/CBO9781107415324.004

De Angelo, L. E. (1981). Auditor Size and Audit Quality. Journal of Accounting and Economics. https://doi.org/10.1016/01654101(81)90002-1

Devi, N. P. A., \& Ramantha, I. W. (2017). Tekanan Anggaran Waktu, Locus of Control, Sifat Machiavellian, Pelatihan Auditor Sebagai Anteseden Perilaku Disfungsional Auditor. E-Jurnal Akuntansi, 18, 2318-2345.

Fatimah, A. (2012). Karakteristik Personal Auditor Sebagai Anteseden Perilaku Disfungsional Auditor dan Pengaruhnya Terhadap Kualitas Hasil Audit. Jurnal Manajemen Dan Akuntansi Volume 1, Nomor 1, April 2012, 1(April), 1-12.

Fitriani, S. I. P. , \& Hanny, R. (2017). Studi Empiris Faktor-Faktor Yang Mempengaruhi Perilaku Disfungsional Audit. Jurnal Akuntansi, 21(02), 184-207.

Ghosh, D., \& Crain, T. L. (1996). Experimental investigation of ethical standards and perceived probability of audit on intentional noncompliance. Behavioral Research in Accounting, 8, 219-244.

Gundry, L. C., \& Liyanarachchi, G. A. (2007). Time budget pressure, auditors' personality type, and the incidence of reduced audit quality practices. Pacific Accounting Review. https://doi.org/10.1108/01140580710819898

Hastuti, R. P. (2013). Kualitas Audit, Tekanan Waktu, Locus Of Control, Komitmen Profesional, Perilaku Penurunan Kualitas Audit. Universitas Gadjah Mada.

Ida Perwati, \& Sutapa. (2016). Pengaruh Locus of Control dan Perilaku Disfungsional Audit Terhadap Kualitas Audit Pada Kantor Akuntan Publik Di Semarang. Jurnal Akuntansi, 5(2), 175-190.

Jaya, Satya Mahendra., Made Sudarma dan Roekhudin 2018. Role Of Auditor Perfomance Mediation In Acceptance Of Auditor Dysfunctional Behavior: Attribution Theory Perpective And Role Theory. Journal of Applied Management, 16(4).

Kelley, T., \& Margheim, L. (1990). The impact of time-budget pressure, personality, and leadership variables on dysfunctional auditor behavior. Auditing: A Journal of Practice \& Theory.

Khudhair, D., Al-Zubaidi, F., \& Raji, A. (2019). The effect of board characteristics and audit committee characteristics on audit quality. Management Science Letters, 9(2), 271-282.

Kristanti, M., Anugerah, R., \& Hasan, M. (2017). Pengaruh Time Budget Pressure,locus of Control, Komitmen Organisasi, Dan Stres Kerja Terhadap Kualitas Audit Dengan Perilaku Disfungsional Audit Sebagai Variabel Intervening (Studi Empris Pada Kantor Akuntan Publik Pekanbaru, Padang Dan Medan). Jurnal Online Mahasiswa Fakultas Ekonomi Universitas Riau, 4(1), 867-880.

Kristianti, I. (2017). Tipe Kepribadian, Penerimaan Perilaku Disfungsional Dan Keputusan Audit. Jurnal Economia, 13(1), 28. https://doi.org/10.21831/economia.v13i1.10906

Kurnia, W., Khomsiyah, K., \& Sofie, S. (2014). Pengaruh Kompetensi, Independensi, Tekanan Waktu, Dan Etika Auditor Terhadap Kualitas Audit. Jurnal Akuntansi Trisakti, 1(2), 49. https://doi.org/10.25105/jat.v1i2.4826

Kurniawan, G., Ngumar, S., \& Kurnia. (2019). Effect Of Time Budget Pressure, Audit Fee, Independence, And Competence On Audit Quality. 7(1), 20-28.

Kustinah, S. (2013). The influence of dysfunctional behavior and individual culture on audit quality. International Journal of Scientific \& Technology Research, 2(5), 118-125.

Lendi, A., \& Sopian, D. (2017). Pengaruh Tekanan Anggaran Waktu dan Locus of Control terhadap Perilaku Disfungsional dalam Audit. Proceddings, 598-610.

Limanto, M., \& Sukartha, I. M. (2019). Analisis Faktor-Faktor Yang Mempengaruhi Perilaku Disfungsional Auditor. E-Jurnal Akuntansi. https://doi.org/10.24843/eja.2019.v27.i02.p02

Mangiwa, C., Bandang, A., Ridwan, H., Ashari, M., \& Lobo, M. T. (2017). The Effect of Locus of Control, Time Budget Pressure, and Professional Commitment on Dysfunctional Audit Behaviour. Journal of Education and Vocational Research (ISSN 2221-2590) Vol. 8, No. 2, Pp. 49-61, June 2017 The, 8(2), 1-9.

Marbun, A. B. S. M. (2015). Pengaruh Kompetensi, Independensi, Profesionalisme, Pengalaman Kerja dan Komitmen Organisasi Terhadap Kualitas Audit. Jom FEKON Vol. 2 No. 2, 2(2), 15.

Martini, N. P. R., \& Pertama, I. G. A. W. (2019). Perilaku Disfungsional Auditor: Dampak Kompetensi Auditor, Sifat Machiavellian, Tekanan Waktu Dan Tekanan Ketaatan (Studi Kasus KAP di Bali). Wacana Ekonomi (Jurnal Ekonomi, 
Bisnis Dan Akuntansi), 18(1), 66-74.

McNair-Conolly, C. J. (1991). Proper compromises: The management control dilemma in public accounting and its impact on auditor behavior. Accounting, Organizations and Society.

Ningsih, A. . P. R. C., \& Yaniartha S., P. (2013). Pengaruh Kompetensi, Independensi, Dan Time Budget Pressure Terhadap Kualitas Audit. E-Jurnal Akuntansi, 4(1), 92-109.

Nor, M. N. M., Smith, M., Ismail, Z., \& Taha, R. (2017). The Effect Of Time Budget Pressure On Auditors' Behaviour. Advanced Science Letters, 23(1), 356-360. https://doi.org/10.1166/asl.2017.7185

Nugraha, D. H. (2016). Pengaruh Locus of Control dan Komitmen Organisasi Pada Perilaku Audit Dengan Tekanan Anggaran Waktu Audit sebagai Variabel Mediasi. Tesis. Fakultas Ekonomi Dan Bisnis Universitas Udayana.

Nurfadilah, \& Junaid, A. (2019). Determinan perilaku etis auditor terhadap kinerja auditor dengan perilaku etis auditor sebagai variabel intervening. Paradoks Jurnal Ilmu Ekonomi, 2, 1-20.

Otley, D. T., \& Pierce, B. J. (1996). Auditor time budget pressure: Consequences and antecedents. Accounting, Auditing \& Accountability Journal, 9(1), 31-58. https://doi.org/10.1108/09513579610109969

Palulu, A. I. A. N., Mus, A. R., \& Lannai, D. (2018). Pengaruh Auditor, Sistem Pengendalian Internal dan Komite Audit Terhadap Audit Delay Pada Kantor Akuntan Publik Se Kota Makassar. 1(1), 96-112.

Pierce, B., \& Sweeney, B. (2004). Cost-quality conflict in audit firms: an empirical investigation. European Accounting Review, 13(3), 415-441. https://doi.org/10.1080/0963818042000216794

Pranyanita, A. . I., \& Sujana, I. ketut. (2019). Pengaruh Sifat Machiavellian, Time Budget Pressure, Loc Pada Dysfunctional Audit Behavior, Akuntan Publik Di Bali. E-Jurnal Akuntansi Universitas Udayana, 26, 1161-1188.

Prawitasaria, P. P., Suardikha, I. M. S., Sari, M. M. R., \& Putra, I. N. W. A. (2018). Tri Hita Karana Culture as a Moderate Influence of Public Accounting Firm Competition and Machiavellian Personality on the Auditor Independence. International Journal of Sciences: Basic and Applied Research (IJSBAR), 41, 1-24.

Primastuti, F. D., \& Suryandari, D. (2014). Pengaruh Time Budget Pressure Terhadap Kualitas Audit Dengan Independensi Sebagai Variabel Intervening (Studi Kasus Pada Bpk Ri Perwakilan Provinsi Daerah Istimewa Yogyakarta). Accounting Analysis Journal, 3(4), 446-456. https://doi.org/10.15294/aaj.v3i4.4206

Purnamasari, P. P. D. (2017). Pengaruh Kompleksitas Tugas, Independensi, Dan Kompetensi Terhadap Kualitas Audit Dengan Integritas Auditor Sebagai Variabel Pemoderasi. E-Jurnal Akuntansi, 19, 2496-2526.

Purnamasari, S. V. (2006). Sifat Machiavellian dan Pertimbangan Etis: Anteseden Independensi dan Perilaku Etis Auditor. Simposium Nasional Akuntansi 9 Padang, 23-26.

Purwaningsih, P. A. V., \& Suputra, I. D. G. D. (2018). Pengaruh Profesionalisme Dan Perilaku Disfungsional Auditor Pada Kualitas Audit Dengan Kepuasan Kerja Sebagai Variabel Moderasi. 24, 224-252.

Rastina, R., Hasiah, H., \& Arsyad, M. (2018). Pengaruh Skeptitisme, Kecerdasan Emosional Dan Locus of Control Terhadap Kualitas Audit. Seminar Nasional Hasil Penelitian (SNP2M PNUP), 2018, 319-324.

Ratha, I. M. D. K., \& Ramantha, I. W. (2015). Pengaruh Due Professional Care, Akuntabilitas, Kompleksitas Audit, dan Time Budget Pressure Terhadap Kualitas Audit. E-Jurnal Akuntansi, 13(1), 311-339.

Rohman, A. (2018). Pengaruh Kompleksitas Tugas, Terhadap Perilaku Disfungsional Auditor Dan. Jurnal Riset Akuntansi Tirtayasa, 03(02), 241-256.

Said, L. L., \& Munandar, A. (2018). The Influence of Auditor'S Professional Skepticism and Competence on Fraud Detection: the Role of Time Budget Pressure. Jurnal Akuntansi Dan Keuangan Indonesia, 15(1), 104-120.

Saputri, I. G. A. Y., \& Wirama, D. G. (2015). Pengauh Sifat Machiavellian dan Tipe Kepribadian pada Perilaku Disfungsional Auditor. E-Jurnal Ekonomi Dan Bisnis Universitas Udayana, 02, 70-86.

Sari, R., Tenriwaru, \& Mokodongan, A. P. (2016). Effect of Time Budget Pressure and Locus of Control of Auditor Dysfunctional Behaviors (Survey on Legislative Auditor BPKP Gorontalo Province). Journal of Education and Vocational Research (ISSN 2221-2590) Vol. 7, No. 1, Pp. 6-13, March 2016, 23(45), 5-24.

Saryati, \& Raden, R. D. (2016). Pengaruh sifat machiavellian dan kompetensi terhadap kualitas audit (Studi Empiris Pada Auditor Badan Pemeriksa Keuangan). Seminar Nasional Dan Call Paper Fakultas Ekonomi UNIBA Surakarta, (September), 412-422.

Setiawan, E., \& Indrawati, N. (2020). The Mediating Effect of Time Budget Pressure on Behavioral Declaration of Audit. Journal of Auditing, Finance, And Forensic Accounting (JAFFA), 7(2), 73-89. https://doi.org/DOI: https://doi.org/10.21107/jaffa.v7i2.6425 JOURNAL

Setiawaty, A. (2013). Audit Quality of Government Auditor. Jurnal Akuntansi Multiparadigma, 4(89). https://doi.org/10.18202/jamal.2013.12.7202

Sihombing, J. (2019). Pengaruh Tekanan Anggaran Waktu dan Kompleksitas Tugas Terhadap Pertimbangan Audit Sampling. Jurnal Kewirausahaan, Akuntansi Dan Manajemen, 1(1), 70-81.

Silaban, A. (2011). Pengaruh multidimensi komitmen profesional terhadap perilaku audit disfungsional. Jurnal Akuntansi dan Auditing (JAA), 8(1), 1-11.

Siregar, H., Muda, I., \& Fachrudin, K. A. (2018). The Impact of Locus of Control, Ethics Audit, Time Pressure, and Commitment to Deviant Behavior in Audit at Foreign Affiliated Public Accountants in Medan, Indonesia. Advance in Social Science, Education and Humanities Research, 292, 416-423. https://doi.org/10.2991/agc-18.2019.64 
Srini. (2015). Uji Multi Stage Pengaruh Karakteristik Personal Auditor Terhadap Kualitas Audit Melalui Perilaku Dysfungsional Audit Dengan Pendekatan Keputusan Berbasis Etis. Jom FEKON, 2(2). https://doi.org/10.1017/CBO9781107415324.004

Sudirjo, F. (2018). Perilaku Auditor Dala Pelaksanaan Program Audit. Serat Acitya - Jurnal Ilmiah UNTAG Semarang, 90101.

Sugiyono. (2017). MetodePenelitian Kuantitatif, Kualitatif dan R\&D. Bandung: PT Alfabet. Sugiyono. (2017). MetodePenelitian Kuantitatif, Kualitatif Dan R\&D. Bandung: PT Alfabet. https://doi.org/10.1017/CBO9781107415324.004

Suprianto, E. (2009). Pengaruh Time Budget Pressure Terhadap Perilaku Disfungsional Auditor ( Audit Quality Reduction Behaviour, Premature Sign-Off \& Under Reporting Of Time ) ( Studi Kasus Pada Kantor Akuntan Publik Di Jawa Tengah). Jai, 5(1), 57-65.

Svanberg, J., \& Öhman, P. (2013). Auditors' time pressure: does ethical culture support audit quality? Managerial Auditing Journal, 28(7), 572-591. https://doi.org/10.1108/MAJ-10-2012-0761

Svanström, T. (2016). Time Pressure, Training Activities and Dysfunctional Auditor Behaviour: Evidence from Small Audit Firms. International Journal of Auditing, 20(1), 42-51. https://doi.org/10.1111/ijau.12054

Sweeney, B., \& Pierce, B. (2004). Management control in audit firms: A qualitative examination. Accounting, Auditing \& Accountability Journal. https://doi.org/10.1108/09513570410567818

Tjun, L. T., Marpaung, E. I., \& Setiawan, S. (2017). Pengaruh Kompetensi dan Independensi Auditor Terhadap Kualitas Audit. Jurnal Akuntansi Vol.4 No.1 Mei 2012: 33-56, 42(1), 91-92. https://doi.org/10.1177/1753193416664491

Trishapsari, D. A., \& Anisykurlillah, I. (2016). Pengaruh Etika,Independensi,Pengalaman Audit Dan Premature Sign Off Terhadap Kualitas Audit. Accounting Analysis Journal, 5(1), 1-7. https://doi.org/10.15294/aaj.v5i1.9756

Turangan, G. M., Karamoy, H., \& Tinangon, J. J. (2016). Faktor-Faktor Yang Mempengaruhi Kualitas Audit Pada Inspektorat Provinsi Sulawesi Utara. Jurnal Accountability. https://doi.org/10.1017/CBO9781107415324.004

Umar, M., Sitorus, S. M., Surya, R. L., Shauki, E. R., \& Diyanti, V. (2017). Pressure, dysfunctional behavior, fraud detection and role of information technology in the audit process. Australasian Accounting, Business and Finance Journal, 11(4), 102-115. https://doi.org/10.14453/aabfj.v11i4.8

Utami, R., \& Sirajuddin, B. (2016). Pengaruh Ukuran Kantor Akuntan Publik (KAP), Masa Perikatan dan Tekanan Waktu Terhadap Kualitas Audit (Studi Kasus KAP di Palembang). Journal of Accounting. Retrieved from http://eprints.mdp.ac.id/1145/1/Jurnal 2010210034 Riska Utami.pdf

Widiani, N. M. N., Sulindawati, N. L. G. E., \& Herawati, N. T. (2017). Pengaruh Tekanan Anggaran Waktu, Tanggung Jawab Profesi, Integritas dan Objektivitas Terhadap Kualitas Audit (Studi Empiris Pada Inspektorat di Bali). E-Journal S1 Ak Universitas Pendidikan Ganesha, 8(2).

Winanda, I. K. H. (2017). Pengaruh Tekanan Anggaran Waktu, Sifat Machiavellian Dan Kompleksitas Tugas Terhadap Perilaku Audit Disfungsional. E-Jurnal Akuntansi, 18, 500-528.

Yuen, D. C. Y., Law, P. K. F., Lu, C., \& Guan, J. Q. (2013). Dysfunctional auditing behaviour: Empirical evidence on auditors' behaviour in Macau. International Journal of Accounting and Information Management, 21(3), 209-226. https://doi.org/10.1108/IJAIM-12-2012-0075

Zam, D. R. P., \& Rahayu, S. (2018). Pengaruh Tekanan Anggaran Waktu (Time Budget Pressure), Fee Audit dan Independensi Auditor Terhadap Kualitas Audit (Studi Kasus Pada Kantor Akuntan Publik Di Wilayah Bandung. E-Proceding of Manajement, 2(2), 1800-1807.

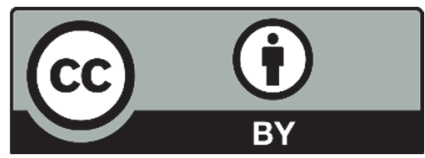

(C) 2020 by the authors; licensee Growing Science, Canada. This is an open access article distributed under the terms and conditions of the Creative Commons Attribution (CC-BY) license (http://creativecommons.org/licenses/by/4.0/). 